\title{
PPP2R2A Gene
}

National Cancer Institute

\section{Source}

National Cancer Institute. PPP2R2A Gene. NCI Thesaurus. Code C134506.

This gene is involved in the regulation of protein phosphatase 2 activity. 